\title{
NP van Wyk Louw: Opstelle vir 'n oorgangstyd ('n voorwoord)
}

Te midde van die Covid-19-pandemie en ingrypende beperkings op die basiese regte van mense deur regerings oor die hele wêreld, merk 18 Junie 2020 vir 'n klein gemeenskap vir wie die klein taal Afrikaans in al haar manifestasies na aan die hart lê, die vyftigste herdenking van die sterfdatum van een van haar heel groot skrywers en rigtinggewende denkers - 'n man wat volgens sommige die Nobelprys vir Letterkunde vir sy lewenswerk moes ontvang het, maar terselfdertyd ook 'n man wie se beskouings tydens sy lewe en veral ná sy dood dikwels uit verskillende, opponerende oorde kritiek (en by geleentheid kritiek-met-oogklappe) ontlok het.

Die vraag, gesien die omstandighede, is watter bydrae 'n gesprek oor NP van Wyk Louw vyftig jaar ná sy dood in die huidige konteks kan lewer, veral ook in die lig daarvan dat die bydraes tot hierdie spesiale huldigingspublikasie vir die grootste deel voor die huidige krisis geskryf is. Antwoorde hierop sal op kort termyn onvermydelik onder meer oorweeg word teen die agtergrond van bepaalde scenario's wat in die krisis opmerklik geword het.

Die wêreld voor die pandemie het reeds baie anders daar uitgesien as tydens die laaste jare van Louw se lewe. Hein Viljoen, in sy bydrae in hierdie uitgawe "Kreolisering en heling in Nuwe verse en Tristia van Van Wyk Louw", som die veranderde dinamiek in 'n skerp toon op:

Afrikanernasionalisme is gediskrediteer, maar die nasionalistiese gedagte (groepsessensialisme) is aan die terugkeer. Afrikaans is onder druk en baie van sy sprekers verengels of verlaat die land. Die Wesfaalse nasiestaat is steeds minder in staat om sy veelrassige en multikulturele bevolkings billik te regeer. Die geïdealiseerde oop gesprek is onmoontlik in situasies van ongelyke magsverhoudings, gebrek aan konsensus en onduidelike gespreksreëls. Selfs die humanisme is gerysmier deur die poststrukturalistiese kritiek op die outonome subjek - gevorm deur diskoerse (van uitsluiting) en blind vir donker kragte uit die onbewuste. Die posthumanisme bevraagteken die oorwaardering van die menslike. Die elektroniese media oorheers die kulturele landskap en reduseer die letterkunde tot 'n randverskynsel. Globalisering vee verskillende tale en kulture op groot skaal uit die pad - en put skaars hulpbronne uit terwyl dit besig is om die planeet onbewoonbaar te maak.

Van die probleme wat Viljoen noem, kan waarskynlik deur die huidige krisis in 'n ander lig gestel word, maar die vrae wat geopper word, bly ter sake en die antwoorde hou gevolge in vir die ná- of leef-met-Covid-19-toekoms: Hoe kan dié Afrikaanssprekendes wat kies om in hierdie land aan te bly en 'n bydrae te lewer, én hulle wat kies om hulle bydrae van 'n afstand te lewer, aan die huidige impasse ontkom; hoe praat ons met mekaar oor historiese probleme in ons soeke na antwoorde vir huidiges; en hoe verreken ons die nalatenskap van die verlede in hierdie proses? Ek sal probeer om aan die hand van die bydraes vir dié geleentheid scenario's te skets wat hopelik suggesties bevat oor hoe antwoorde na vore (kan) tree.

Een scenario waaraan op openbare platforms tans baie aandag gegee word, manifesteer in die botsende belange en regte wat die huidige Covid-19-pandemie aanwakker en die grense wat in die proses tussen $e k$ (ons) en die ander getrek is/word - kwessies en grense (of limiete 
in die filosofiese woordeskat) wat tegelyk polities, ekonomies, staats-/burgerregtelik, moreeleties persoonlik, groepspesifiek, nasionaal of globaal van aard is, tydelik of meer permanent, informeel of geïnstitusionaliseer - dus: onontwykbaar verwikkeld. Om van die dilemmas wat die pandemie na vore bring, konkreet by algemene lesers tuis te bring, het Johann van der Westhuizen (2020:7), voormalige regter van die Konstitusionele Hof, in Rapport in Mei na opruiende koerantopskrifte dat die regering se inperkingsmaatreëls nie langer geregverdig kan word nie, die volgende toneeltjie geskets:

Liewe leser, stel uself as regter aan. U hof word genader vir 'n bevel teen die president om die rampbestuurbeperkings op te hef omdat dit meer lewens sal kos as red? Gee getalle die deurslag? Mag 100 lewens willens en wetens opgeoffer word vir elke 1000 wat gered word? Oor 'n week, maand, of dekade? Maak dit saak of die 100 - of die 1000 - kinders of oues van dae is? En of hulle in Sandton of Diepsloot woon?

Wees versigtig. Covid-19 sal verbygaan. Ander krisisse wag. Die wêreld kan terugkeer na beproefde uitwissingstegnieke soos oorlog en terrorisme. Nuwe siektes is op pad.

Elke dag voeg stringe ander praktiese voorbeelde by: in die eerste weke byvoorbeeld was dit die spanninge tussen die daaglikse, noodgedwonge en ongeërgde oortredings van inperkingsmaatreëls wat getref is met die doel om menselewens te beskerm, enersyds, en, andersyds, die lyding, wydlopende skade en kriminaliteit wat deur daardie selfde maatreëls teweeggebring word. Maar soos wat die wêreld vanuit die onmiddellike krisis voel-voel na 'n nuwe "normaal" begin beweeg, sal nuwe dubbelstandaarde in die praktiese toepassing van reëls opduik én daarmee saam ook vrae oor die billikheid/willekeurigheid van bepaalde reëls gestel word wat lank ná die krisis van die oomblik sal bly náwerk in die sosiaal-politieke lewe van nasies. En sal daar ook opnuut weer vrae gevra word oor die regsbeginsels wat moet geld.

"Reg" en "onreg (individuele en nasionale)", "regte", "geregtigheid" en die "regsidee" is komplekse sake waaroor Louw hom meermale sterk uitgelaat het, hoewel hy, soos Derek van der Merwe in sy bydrae in hierdie uitgawe "Die geregtigheidsideaal by NP van Wyk Louw" opmerk, nooit die positiewe reg van die staat tematies onder die loep geneem het nie. Van der Merwe spekuleer oor redes hiervoor en opper onder meer die moontlikheid dat die werkwyse op die terrein van die positiewe reg met die "aandrang ... dat daar net één regte - of ten minste gesaghebbende - antwoord kan wees wanneer 'n regspreker moet kies tussen botsende aansprake of belange," teenstrydig is met die werkwyse wat Louw aan die intellektueel opdra: "die onsekere spel van die rede, van die opweeg van argument teen argument en die swewende balans wat vry van die keuse en die handeling en die bitterheid bly".

Van der Merwe se formulering werp sydelings lig op die paradokse inherent aan die huidige krisisse waarin beide optrede na die een of ander kant toe of onwilligheid om op te tree (of bloot algemene passiwiteit) verreikende eties-morele implikasies het. Wanneer Van der Merwe se bydrae saam met onder meer Willem J Botha se bydrae "Die daad onthul (im)moraliteit" gelees word oor die komplekse verhouding tussen daad en moraliteit in Louw se versdrama Germanicus en ander werke en Benda Hofmeyr se opstel oor lojale verset vandag "Lojale verset: Gedateerd of aktueel? NP van Wyk Louw in gesprek met Foucault" word gespreksmoontlikhede geopen wat verreikende implikasies inhou vir die beoefening van kritiek in krisisomstandighede. Louw (1956) se Germanicus kan trouens as toetssteen geld vir verskillende kwessies wat in hierdie huldigingspublikasie aan die bod kom. Onder andere bring die drama verskeie kwessies rondom mag, leierskap, intellektualiteit en driftelikheid, moraliteit, opstand en voortbestaan wat Louw ook in sy beskoulike opstelle en ander kreatiewe werk besig gehou het, veraanskoulik onder woorde - aangeleenthede wat verskeie bydraers opnuut met 
dringende verwysing na die toekoms van Afrikaans en haar sprekers in die afsienbare toekoms opneem.

Germanicus is 'n drama waarin die taalgebruik 'n prominente rol speel. Jo-Marie Claassen (2013) wat die drama in Engels vertaal het, wys byvoorbeeld in haar inleiding op die besondere kompaktheid van Louw se taalgebruik wat die adage dat Afrikaans dinge nie so kompak as Engels kan uitsê nie op die kop keer. Die uitsonderlike seggingskrag van Louw se taalgebruik kom ook in verskeie bydraes in hierdie huldigingspublikasie ter sprake (kyk verder aan). Na die oordeel van Rob Antonissen (1962:8, 180-185) slaag Germanicus veral juis uitmuntend as 'n radiodrama, met ander woorde as 'n stuk wat noulettende aandag vir die gesproke en gehoorde woord vra: vir Antonissen was Germanicus bowenal 'n psigologiese idee-drama en 'n "sublieme dispuut". Willem Botha verwys in sy bydrae verder na TT Cloete se beskouing in $O p$ die woord af (1963) dat in Germanicus die woord "self dramatiese figuur, handelingsmoment" word, "karakters ... maklik agter hulle woorde (verdwyn)" en "duistere of magswoorde" (soos heers, heersersras, heersersreg, mag, krag, trots, vrees, haat, asook daad) 'n soort "familiale bestaan" binne die versdrama voer. Via die opvattings van taalkundiges soos Anton Reichling en JL Austin herinner Botha ons ook weer daaraan dat taalgebruik in die algemeen ' $n$ handeling is (en by implikasie dat kritiek 'n daad of optrede is): "dat taal in der waarheid self daad is en dat deur taaldade die wêreld verander (kan) word".

Soos kritici al aangetoon het, verwys Germanicus nie eksplisiet na 'n herkenbare SuidAfrikaanse situasie nie, maar uit JC Steyn (1998:403 e.v.) se biografie van Van Wyk Louw blyk bepaalde aktualiteite waarmee Louw gepreokkupeer was tydens die ontstaan van Germanicus, met enkele vroeë aantekeninge reeds in 1941 en 'n toegewyde skryfperiode wat min of meer van 1944-1948 (die jare tydens en onmiddellik ná die Tweede Wêreldoorlog) gestrek het, waaronder die "voortbestaan" van "ons taal", die "lot v. volke \& die hart v/d mens". Die bewussyn van hierdie preokkupasies rig ook, tesame met Louw se eie verduideliking in Rondom eie werk van die ontstaan van een van sy bekendste gedigte "Die beiteltjie", Helize van Vuuren se radikale herinterpretasie van dié gedig in hierdie herdenkingspublikasie, 'n gedig wat volgens haar berekening iewers in die tyd rondom die bewindsoorname deur die Nasionale Party in 1948 (of selfs in die maande net daarná, volgens spekulasie) ontstaan het.

Nog 'n sentrale gedagte in Germanicus wat tans weer resoneer is dié van 'n oorgangstyd (die krisismoment wat teken is dat die gevestigde oue onherroeplik aan die verbygaan is, terwyl die nuwe nog sukkel om duidelike beslag te kry). In 'n brief aan sy toenmalige vriend, die digter Jan Gresshoff, in Maart 1944 skryf Louw (in Steyn 1998:406) in 'n toon wat iets van die pessimisme verraai wat in Van Vuuren se herlees van "Die beiteltjie" bykans agt dekades later teruggevind word:

My lees die afgelope tyd was gedurig in verband met die Rome van die Keisertyd: eers Mommsen, toe Gibbon en Burkhardt; gedurig tussenin Tacitus en Suetonius (want my drama speel in die tyd van Tiberius) en dan is dit net ondergang, stilword van die geestelike lewe voor die brute magte, onseker oorgange na nuwe dinge - dit is al wat ek sien in 'n tyd wat in baie opsigte soos ons eie is.

In die lig van die bogenoemde kan die bydraes in hierdie herdenkingspublikasie, gesien die ooreenkomste weer van Louw se tyd met ons s'n, dalk ook beskryf word as: opstelle met die oog op 'n oorgangstyd.

Derek van der Merwe gryp in sy bydrae terug na twee van Louw se vroeë stukke, die drama Die dieper reg en die essay "Die ewige trek", wat albei dateer uit 1938, die jaar van die honderdjarige herdenking van die Groot Trek, met belangrike insette van Van Wyk Louw, 
waarna JC Steyn ook in sy bydrae verwys. Van der Merwe is veral geïnteresseerd in Louw se "verwoording van die Platoniese regsidee as die nastrewenswaardige, maar onbereikbare, sneeupunt van die denke" en argumenteer dat Suid-Afrika se Grondwet in waardes en beginsels die weg kan baan om aan Van Wyk Louw se regsideaal uitdrukking te gee. Die parentese in een van die slotsinne in die betoog vra egter dat die leser ook met 'n fyn oog sal kyk na Benda Hofmeyr se stuk. Die "regsidee", sê Van der Merwe,

die volkome uitleef van die demokratiese waardes van menswaardigheid, gelykheid en vryheid, is 'n dieper reg wat in die onbereikbare sneeupunt van die denke neerslag vind. Maar die bewuste strewe na daardie dieper reg is kernbelangrik. Die dryfkrag daarvoor lê in 'n "loyalty to loyalty", 'n getrouheid aan die trou verwoord in die grondwetlike koningstem. Sonder so 'n bewuste "loyalty to loyalty" - en tans het ons dit nie - is ons bloot besig met swaar, dom, lomp besluiterighede.

In haar huldigingsbydrae by hierdie geleentheid, waarin Van Wyk Louw se "lojale verset" en Foucault se interpretasie van Bataille se konsep "transgressie" saamgelees word om optredes binne huidige kontekste vir huidige probleme te bedink, gebruik Benda Hofmeyr die begrip "dubbelbinding" soos dit in die filosofie van Friedrich Nietzsche aangetref word - 'n begrip wat op ' $n$ besondere wyse in 'n Covid-19-wêreld en ook in meerdere bydraes in hierdie herdenkingspublikasie weerklank vind. Dubbelbinding verduidelik Hofmeyr na aanleiding van 'n uitspraak van Louw in Lojale Verset dat "die patos van ons menslike strewe is dat ons keer op keer uitgaan om die geregtigheid te verwesenlik en dat ons stelsel tot onreg lei ...; dat ons die vryheid soek totdat ons stelsel weer ander verkneg," as "die noodsaak tot ingrepe en die onvermydelike ongeregtigheid waartoe dit uiteindelik lei ongeag enige edele motiewe".

Foucault se hantering van die begrippe limiet en transgressie werp lig op kwessies soos inperking en oortreding binne spesifieke kontekste. Dit is egter Hofmeyr se byeenbring van Louw se "lojale verset" en Foucault se "transgressie" in 'n betoog wat die oorskryding van beperkinge stel binne die wederkerige spanningsverhouding tussen lojaliteit en verset, wat besondere moontlikhede vir die rol van kritiek in die samelewing vandag, in "dié tyd en in hierdie 'sonderlinge plek' oopmaak".

Hofmeyr wys daarop dat Louw, soos Foucault, selfingenomenheid ter wille van selfoorskryding afwys. In Louw se eie woorde ontstaan groot kritiek "wanneer die kritikus hom nie buite nie, maar in die midde van die groep stel wat hy kritiseer ... nie praat van 'hulle' nie, maar van 'ons' ...". Groot kritiek kan in hierdie opsig dus ook beskou word as 'n vorm van transgressie van eie beperkinge en die debat oor kritiek sal daarby baat om Hofmeyr se betoog oor die limiet en transgressie fyn te lees.

Verskeie ander opstelle in die herdenkingspublikasie sny temas aan wat Louw in sy oeuvre aan die orde gestel het waarin die teenstrydige kragte en begrensdhede wat ons menslike bestaan in persoonlike en sosiale verband kenmerk, ter sprake is, wat direk of indirek (en selfs onvoorsiens) op komplekse dilemmas in die hede betrek (kan) word. Een van die temas met so 'n verwikkelde dubbelbinding waaraan denkers en navorsers wat hulle ernstig met Louw besig hou, steeds nie kan ontsnap nie, is die groepsgedagte - Afrikanernasionalisme of wat JC Steyn in sy bydrae (Louw se) Afrikaanse nasionalisme noem - in sy denke. Selfs kritici wat uitgaan van die standpunt dat die konsep vir die groep Afrikaanssprekendes wat hulle met die taal vereenselwig, sedert 1994 nie meer enige relevansie het nie, moet dit desondanks nóém. Hóé om by die idee verby te kom sonder om noodwendig die gedagte van 'n verbonde groep of die taal terselfdertyd te verloor of prys te gee, is 'n vraag wat steeds bly spook; wat kom in die plek van 'n (uitgediende) Afrikanernasionalisme? Die dubbelbinding blyk vir 
Afrikaanssprekendes in Suid-Afrika steeds te wees hoe om die limiet van 'n nasionalisme te oorskry in 'n land waarin die nasionalistiese gedagte steeds die toon aangee - 'n vraag wat sowel skrywers as kritici besig hou. Sou Steyn se Afrikaanse nasionalisme, met ander woorde 'n taalnasionalisme, 'n antwoord bied? Te oordeel aan Hein Willemse (2019) se essay-resensie van Steyn se Verset en opbou. Skrywers en politici as aktiviste vir Afrikaans, wat hy oordeel bruin en swart Afrikaanssprekendes steeds uitsluit, is die antwoord nee. Bydraes in hierdie publikasie, blyk dit, soek ook eerder na moontlike antwoorde, en, in die geval van Hein Viljoen byvoorbeeld, in direkte aansluiting by Willemse. Twee bydraes wat spesifiek bemoeienis maak met die kwessies van nasionalisme en die de- en postkoloniale, is die opstelle van Louise du Toit en Hein Viljoen, wat eweneens sinvol saamgelees kan word:

Viljoen se vertrekpunt is dat die sentrale raamwerke waarbinne Van Wyk Louw gedink het - van Afrikanernasionalisme en Afrikaans tot die oop gesprek en die humanisme - vandag "heelwat van hulle geldigheid verloor" het. In sy eie woorde:

Suid-Afrika is vandag 'n tipiese postkolonie, waarin oorgelewerde én nuwe strukture disjunk is van die leefwyse van gewone mense. ... Die land is nog steeds op soek na nuwe maniere om die self en die ander te versoen en terselfdertyd die wanbalanse van die verlede te herstel en die jong demokrasie te versterk. Die uitdaging is om anders te begin dink oor self, ander, taal, letterkunde, nasie, die planeet, ons leefwyse. 'n Helende ander soort denke is kortom nodig.

Viljoen stel die nasionale teenoor die postkoloniale en die nuwe denkraamwerk wat hy aan die hand doen om die huidige impasse in Afrikaanssprekende geledere te oorkom, in aansluiting by vroeëre uitsprake van Hein Willemse en die opvattings van die Karibiese skrywer Édouard Glissant, is kreolisering, 'n denkraamwerk wat ontwikkel moet word op die aanvaarding, eerstens, dat Afrikaans 'n kreoolse of bastertaal is en, tweedens, dat "daar goeie gronde is om die Afrikaanse letterkunde (of selfs die Suid-Afrikaanse letterkunde) ook as die produk van kreolisering te beskou - die produk van die kreatiewe vermenging van verskillende vertel- en skryftradisies binne 'n derde ruimte". In Louw se laat werk, in Nuwe verse en Tristia, meen Viljoen, vind hy belowende tekens van so 'n ontwikkelende nuwe denkraamwerk en praktyk wat binne 'n transnasionale ruimte tereg kan kom. ${ }^{1}$

Net om verdere konteks te gee aan die verwysing na die transnasionale as ruimte vir nuwe denkraamwerke: Louise Viljoen (2014:4-6) gebruik reeds in 2014 in 'n artikel die term "transnasionalisme", wat in die sosiale wetenskappe "veral verwys na die ekonomiese, sosiale en politieke verbindinge tussen mense, plekke en institusies oor die grense van nasionale state heen," op 'n wyse wat suggereer dat literêr-kulturele transnasionale beweeglikheid dit vir kleiner letterkundes en tale - minstens teoreties - moontlik maak om danksy sekere skrywers oor die sosio-politieke beperkinge van die "tuiskultuur" te tree om so hulle invloedsfeer na "buurletterkundes" toe uit te brei en aan die "grootboet"-kulture deel te neem. Sy fokus in haar artikel op "die wyse waarop die letterkunde in Afrikaans as '"n marginale taal in 'n marginale land' deel het aan 'n transnasionale beweging oor grense heen" met verwysing na die Nederlandse ontvangs van spesifieke skrywers wat internasionale politieke en intellektuele geloofwaardigheid verwerf het, soos André Brink, Breyten Breytenbach, Etienne van Heerden, Antjie Krog en Marlene van Niekerk.

Hein Viljoen se bydrae oor kreolisering in Nuwe verse (1954) en Tristia (1962) en Helize van Vuuren se "lees" van "Klipwerk" in Roggeveldse konteks in haar bydrae maak 'n boeiende leesavontuur. 
Ook Andries Bezuidenhout (2018) sien in 'n transnasionalisme 'n uitkoms uit die doodloopstraat van die Afrikaanse kultuurlewe. Hy begin sy NP van Wyk Louw-gedenklesing in 2018 met 'n vraag: "My kernvraag handel oor die rol van verbeelding in sosiale omwentelings, asook kwessies oor die voortbestaan, al dan nié, van 'n Afrikaanstalige kultuurlewe. Dis 'n betoog vir 'n talige transnasionalisme, eerder as taalnasionalisme." En sluit af: "Dalk is dit lankal reeds te laat, 'n verspeelde lente. Aan die ander kant bly daar die verbeelding. Miskien moet diegene van ons wat'n Afrikaanstalige kultuurlewe ánders wil bedryf eerder heterotopieë in kleiner ruimtes opsoek, hier in Suid-Afrika en op ander plekke -'n talige transnasionalisme."

Ek stel my voor dat die dramaturg Tertius Kapp sal redeneer dat kunstefeeste vandag sulke heterotopiese ruimtes skep. Kapp (2015) kyk nie transnasionaal na ruimtes buite die Suid-Afrikaanse konteks vir antwoorde nie en ook nie soseer na groepservarings nie (hy het trouens min ooghare vir Louw se sentimente en metafore); sy blik in sy NP van Wyk Louwgedenklesing is op Suid-Afrika in 'n postnasionale konteks:

As Afrikaans dan belangstel om die soort werk voort te bring wat op hierdie wyse [esteties - RJ] sy bestaan kan regverdig, lyk dit vir my onwaarskynlik dat dit deur 'n afgewaterde namaaksel van Westerse kultuurvorme kan gebeur. In sy prognose vir Afrikaans beskryf Van Wyk Louw dit as 'n taal wat "suig uit twee bronne", wat

'n brug vorm tussen die groot helder Weste en die magiese Afrika - die soms nog so onhelder Afrika; hulle is albei groot magte, en wat daar groots aan hulle vereniging kan ontspruit - dit is miskien wat vir Afrikaans voorlê om te ontdek.

Dit is ook in my siening die potensiaal wat vir Afrikaans voorlê. As die interne spanning tussen die verskillende vorme van Afrikaanse kultuur gemobiliseer kan word, word die kunstefeeste, in stede van 'n kulturele nessie, 'n arena waar kulturele spanning uitgespeel kan word. Daar is baie energie opgesluit in hibriditeit, en kultuurleengoed, kulturele toeeiening, is 'n algemene en oorwegend gesonde verskynsel. Die mees suksesvolle kultuurverskynsels van die moderne era vertoon almal hierdie kenmerk. As wit Afrikaans nie generies wil word nie, kan hy sy lesse gaan leer by die geskiedenis van bruin identiteit: leen, en leen wyd, maar makk jou leengoed jou eie.

Kapp praat by implikasie dus ook van kreolisering, maar vanuit ' $n$ ander ingesteldheid as Hein Viljoen. Vir Viljoen is kreolisering in die eerste instansie 'n denkraamwerk, vir Kapp is dit, vermoed mens, geleefde werklikheid, waar verskillende herkenbare identiteite langs mekaar op die markplein van onder meer die kunstefeeste tot uitdrukking kom. In sekere opsigte stel Kapp die titel van Louise du Toit se betoog in die vooruitsig, en haar verduideliking daarvan: "Sowel in temporele as in ruimtelike dimensie moet die saam- en gelyktydige bestaan van 'n groot verskeidenheid selfstandige perspektiewe erken word".

In “'Die pot kook oral': NP van Wyk Louw, Johannes Degenaar en Afrikaanse dekolonisering" lees Du Toit Louw vanuit 'n dekoloniale raamwerk saam met Franz Fanon en Walter Mignolo se standpunte oor kolonialiteit en dekolonialiteit. "Kolonialiteit", herinner Du Toit ons, is ' $n$ houding en mentaliteit wat lank ná die formele bevryding van die kolonie voortleef. Sy argumenteer voorts dat wanneer Louw se uitsprake oor die voortbestaan van die Afrikaner en 'n eie letterkunde geplaas word binne die historiese raamwerk waarin dit ontstaan het, die parallelle met die hede duidelik word en dat Louw in dié lig as 'n protodekoloniale denker na vore tree. Soos Du Toit dit in Engels opsom:

When Louw's turn to nationalism is understood as a form of "decolonisation" or an attempt to address critically and overcome the colonial mentality, or so my argument goes, new 
and fresh light might be shed on his ideas. The other side of the coin is to use the Afrikaner's turn to nationalism in order to cure coloniality as a cautionary tale about the pitfalls of precisely such an enterprise.

Wat uit die bogenoemde bydraes na vore kom, is bewyse van nuwe raamwerke wat in plek gestel word om uit die impasse ten opsigte van groepsbehorendheid los te wikkel wat talle Afrikaanssprekendes vir wie Afrikaans belangrik is, steeds ervaar en om deelname in die groter ruimtes moontlik te maak; daarmee saam ook standpuntinnames oor die ingesteldheid en grondreëls wat kritiek en ander optredes binne hierdie raamwerke kan dryf. Dit is die intellektuele gesprek wat hierdie bydraes moontlik maak wat tot die tweede scenario spreek.

Dié scenario kan onder meer afgelees word uit die betreklike gemak waarmee intellektuele gesprekke, opvoedkundige praktyke en artistieke bedrywighede wat tot dusver op persoonlike kontak gefloreer het tydens die pandemie aanlyn geneem en uitgebrei is en in die proses oor allerlei grense heen beskikbaar gestel is, ook aan mense wat voorheen nie toegang hiertoe gehad het nie, wat die moontlikhede vir die verwerwing en verdieping van kennis en die deelname aan die intellektuele gesprek na groter gemeenskappe onmeetlik uitbrei - 'n inisiatief wat ook met hierdie herdenkingsgeleentheid aangegryp word deur die beskikbaarmaking van die bydraes op verskeie platforms.

Wat opmerklik is van die bydraes by hierdie geleentheid, is hoe verskeie daarvan, ten spyte van uiteenlopende uitgangspunte, met mekaar in gesprek tree, argumente vanuit verskillende dissiplines belig en standpunte kwalifiseer. Hoewel te verwagte in 'n akademiese konteks, is dit merkwaardig hoe uiteenlopend die benaderings tot Louw se nalatenskap in die bydraes vir hierdie publikasie is en wie die gesaghebbendes is wat betrek word om standpunte te help verduidelik of te ondersteun: vanuit die biografiese geskiedskrywing (JC Steyn) en benaderings tot die historiografie wat dié soort geskiedskrywing onderlê (met verwysing na die vertaal- en romankunde; Hennie van Coller), vanuit die teaterresepsiekunde (met poststrukturalistiese invloed; Marisa Keuris), die regswetenskap (Derek van der Merwe) en die filosofie (met verwysing na Johan Degenaar en dekoloniale denkers soos Franz Fanon, Walter Mignolo en Kwasi Wiredu; Louise du Toit, en na Friedrich Nietzsche en Michel Foucault, veral laasgenoemde se opvattings oor "limiete" en "transgressie" soos reeds duidelik geraak het; Benda Hofmeyr), vanuit die postkolonialisme (met verwysing na die Karibiese skrywer Édouard Glissant se postkoloniale opvattings oor kreolisering; Hein Viljoen), die ekokritiek en dierestudies met verwysing na Martin Heidegger, Jacques Derrida en Frans de Waal (Johann Lodewyk Marais, wat met nuwe insigte terugkeer na sy 2006-opstel in die herdenkingsuitgawe van Tydskrif vir Geesteswetenskappe met die oog op Louw se honderdste verjaardag), taalkunde, pragmatiek, kognitiewe semantiek en korpuslinguistiek (Jac Conradie, Nerina Bosman en Willem J Botha), getuienisgeskiedenis (Anastasia de Vries wat in haar bydrae wys op "the cultural debt the Catholic Church and especially her Afrikaans speakers owe Van Wyk Louw”), klassieke genrestudies (Heilna du Plooy), die vergelykende literatuurwetenskap en die stipleestradisie (met 'n sosiaal-politieke wending; Helize van Vuuren) en inligtingskunde, kanonstudies en literatuurkritiek (Ronél Johl).

In haar bydrae oorweeg Johl enkele ontwikkelinge op die terrein van die (literatuur)kritiek en kanonstudies sedert die eeuwending sover dit "bewysvoering" binne die betrokke kontekste betref. Sy neem enkele gesaghebbende literêr-kritiese (her)takserings van Louw se statuur in die kanon rondom die eeufeesherdenking van sy geboorte as vertrekpunt, met aandag veral aan bepaalde verskuiwings wat besig is om op die terrein van taksering in te tree waar toenemend op die beskikbaarheid van betroubare data en grootdataverwerking gesteun word en argumenteer dat nuwe insigte oor die statuur en postuur van die groot Afrikaanse skrywers 
op die wyse moontlik gemaak kan word. Sy sluit af met die suggestie dat die byeenbring van groot datastelle reeds daarop wil dui dat Van Wyk Louw steeds standhoudend die sterkste figuur in die Afrikaanse kanon is.

'n Tydige herinnering aan die fundamentele bydrae wat 'n deeglike taalkundige kennis in gesprekke oor dissiplinêre grense heen oor 'n meester van die taal soos Van Wyk Louw (soos vroeër reeds aangetoon) kan lewer, kom van die bevindinge van drie taalkundiges hier bo se bydraes in hierdie herdenkingspublikasie: Botha, Conradie en Bosman. Botha, wat soos hoër op gewys, aantoon hoe kompleks 'n konsep soos daad in Louw se denke is en hoe dit presies met moraliteit skakel. Jac Conradie, wat met uitvoerige voorbeelde uit Louw se oeuvre aantoon hoe die woordsmid met meesterlike aanwending van relativering op 'n verskeidenheid terreine korrektiewe aanbring en nuwe perspektiewe open:

Met 'n aantal - bewuste of onbewuste - tegnieke wat dikwels herlei kan word tot die alledaagse spreektaal, slaag Van Wyk Louw nie net daarin om deur relativering treffende kontraste te skep nie, maar ook om persone, situasies en gedagterigtings te kenskets en ironiseer, en talle sake in perspektief te stel sonder om in selfverydelende relativisme te verval.

En Nerina Bosman wat, met trapsgewyse teoretiese ondersteuning en korpusstatistiese bewysvoering, aantoon hoe 'n ["rustelose" - RJ] konsep soos beweging, en die duratiewe gaan méér as kom, Louw se denke tot in sy heel laaste gedig in Tristia, "Groot ode", aanvuur:

Die eindbestemming, wat dit ook al mag wees, is nooit die fokus in hierdie gedig nie. Die begin en die pad, die reis self - dit is waaroor dit gaan. Daar is ook die koppige weiering om te rus, die uitskreeu na ánders as hy is. Daar word nie aangekom by 'n bestemming in "Groot ode" nie.

Helize van Vuuren beskryf haar bydrae as 'n poging om, los van die gevestigde kritiese vooroordele, bepaalde gedigte uit Louw se laatwerk asof vir die eerste keer te lees en die betekenismoontlikhede van enkelwoorde en frases daarin te ontgin en te kyk waarheen dit lei:

Teen die agtergrond van die soort stiplesings van sy werk wat die oeuvre kenmerk weens die gekanoniseerde statuur daarvan, asof in yster gegiet (ook my eie in Tristia in perspektief uit 1989), is dié essay 'n herlesing, 'n wyer lesing, 'n lesing oper na alle kante toe, asof vir die eerste keer, teen alle gevestigde gesedimenteerde opvattings in, met die doel om los te kom van die "groenspaan" van aangepakte kritiese opvattings, soos Louw dit in Rondom eie werk (1970:12) noem...

Die wyse waarop Conradie en Van Vuuren se onderskeie lesings van "Die beiteltjie" teen mekaar aanstoot, maar ook onverwags ondersteun, behoort vir gesprek te sorg. Soos Conradie immers aantoon, nooi die spreker in dié gedig self tot dialoog uit met sy "aanhegvragie":

só moet 'n beitel slaan

wat beitel is, of hoé?

Hiermee ... word die hoorder uitgenooi om deel te neem aan die evaluering van die beitel. So hou die meeste vrae ' $\mathrm{n}$ relativering van die waarheid van die spreker se stelling in; selfs retoriese vrae - wat in wese mededelings is - het ten doel om minstens die hoorder se aandag te kry.

'n Ander gesprek is opmerklik in die bydraes van JC Steyn en HP van Coller, wat hulle albei met geskiedskrywing bemoei. Steyn is skrywer van onder meer die biografieë van M.E.R. en 
Piet Cillié, en ook van die invloedryke tweedelige literêre biografie van Van Wyk Louw, Van Wyk Louw - 'n Lewensverhaal, wat sedert die verskyning daarvan vir Louw-navorsers 'n standaardnaslaanwerk geword het, en waarna in verskeie bydraes in hierdie publikasie ook verwys word. Van Coller, huidige redakteur van die tans driedelige Perspektief en profiel: ' $n$ Afrikaanse literatuurgeskiedenis, het onlangs in 'n huldigingsbydrae die eersgenoemde twee biografieë van Steyn krities in oënskou geneem (Van Coller 2019); in sy bydrae by hierdie geleentheid neem hy Steyn se werkwyse in die Van Wyk Louw-biografie krities onder die loep aan die hand van opvattings uit die vertaal- en die romanteorie.

Daar bestaan, afgesien van Steyn se "lewensverhaal", natuurlik ook talryke korter lewensketse van Van Wyk Louw in publikasies én op die internet, party meer generies en ander vanuit spesifieke belangstellingshoeke, sodat mens met groot belangstelling kyk na sy aanpak van die kort skets vir dié huldigingspublikasie, na bepaalde beklemtonings daarin en na wat "nuut" oor "die onderwerp" gebring word. Lesers wat oor die jare min of meer tred gehou het met die kritiek op Louw en wat die bydrae fyn lees, sal wel agterkom dat Steyn in sy ontvouing van die geskiedenis ook korrektiewe aanbied vir van die vernaamste punte van kritiek op Louw, feite herbeklemtoon of andersins van die kontroversiële aspekte rondom Louw binne kontekste aanbied wat voorheen moontlik nog nie ernstig oorweeg is nie. In die Afrikaanse "opsomming" antwoord Steyn verder ook saaklik op van die kritiek op sy werkwyse in die Louw-biografie.

Van Coller se benadering tot Steyn se literêre biografie van Louw stel fundamentele vrae aan die orde vir geïnteresseerdes in die biografie as genre. ' $n$ Belangrike vraag het te make met die legitimering van die studie van die literêre biografie as 'n volwaardige akademiese (sub)dissipline. Richard Bradford (2019:2) wys byvoorbeeld onlangs op die in die algemeen nog problematiese status van literêre biografieë in die akademiese konteks vanweë die gebrekkige opvoedkundige en teoretiese raamwerke vir die bestudering van die genre - 'n standpunt wat dié van verskeie navorsers in Michael Benton (2009:3) se vroeëre Literary Biography. An Introduction eggo. Onder die laasgenoemdes tel ook 'n uitspraak van Ira Nadel (in Benton 2009:3) oor die afwesigheid van "a sustained theoretical discussion of biography incorporating some of the more probing and original speculations about language, structure, and discourse that have dominated post-structuralist thought". Nadel se uitspraak roep Stephanus Muller se Nagmusiek (2014) op, 'n metafiksionele biografie van die Afrikaanse komponis Arnold van Wyk, waarin Muller die skryf van 'n biografie van 'n kunstenaar uit die apartheidsera in 'n marginale taal soos Afrikaans as akademiese projek radikaal problematiseer. Nagmusiek is 'n werk waaraan Afrikaanse hoofstroom-akademici, ondanks die monumentale skaal van die werk, die verskeie pryse wat dit ontvang het en die belang van die probleme wat daarin aangesny word, omtrent nog glad nie geraak het nie.

Bepaalde opmerkings in Engelse besprekings van JC Kannemeyer $(2011$; 2012) se eweneens hoogaangeskrewe biografie van nobelpryswenner JM Coetzee en nou die kritiekby-nabetragting op Steyn se Louw-biografie gee egter blyke dat dit vir die literêre biografie in die 21 ste eeu waarskynlik nie meer "business as usual" kan wees nie en dat literêre biograwe en kritici kennis sal moet neem van die ontwikkelende teoretiese denke oor die genre. ${ }^{2}$

2 Nuttige vertrekpunte is die besprekings van Clarkson, Carrol. 2014. J.M. Coetzee: 'n Geskryfde Lewe./J. M. Coetzee: A Life in Writing. Life Writing, 11(2):263-270 en die kritiese tipering van die Kannemeyer-biografie in 'n bespreking in The Irish Times as "an old-style literary-critical biography". https://www.irishtimes.com/culture/books/jm-coetzee-a-life-in-writing-by-jckannemeyer-trans-michiel-heyns-1.1481912. 
By afwesigheid van 'n gevestigde akademiese dissipline vir die bestudering van die literêre biografie as genre in Afrikaans beroep Van Coller hom op die skopus- en romanteorie as grondslag vir sy kritiek op Steyn se onafhanklikheid en die objektiwiteit van aspekte van sy Louw-biografie, waardeur ' $n$ interessante dubbelbinding ontstaan: Steyn bied immers die Louw-biografie as 'n "verhaal” aan. Marisa Keuris se aanhaling van Willie Burger (2015) in haar bespreking van die kritiek op Louw se behandeling van historiese materiaal in Die pluimsaad waai ver bied miskien 'n goeie aanknoping vir verdere gesprek oor beide die literêre biografie en die kritiek daarop:

Ten opsigte van geskiedskrywing in die algemeen lei hierdie opvattings (poststrukturalisme - RJ) tot die argument dat die geskiedenis (as 'n "eksterne faktor" waarteen die "waarheid" van historiese fiksie gemeet word) reeds problematies is (soos ook deur White in Tropics of Discourse aangedui is). Die besef dat die geskiedenis nie 'n omvattende en volledig toetsbare weergawe van die verlede kan wees nie, maar dat dit altyd 'n verhaal óór daardie verlede is, het verskeie implikasies - veral vir 'n eenvoudige vergelyking van feit met fiksie.

In die lig van die scenario's wat tot dusver geskets is sou 'n mens in die konteks van die huidige publikasie dus kon praat van inter- en transdissiplinêre (selfs pluralistiese - 'n kyk deur meervoudige lense) benaderings tot Louw se nalatenskap wat ook oor die tradisionele genregrense van Louw se oeuvre heen beweeg en 'n wyer groep belangstellendes wil bereik.

'n Laaste scenario waarop ek met die oog op 'n vraag oor die relevansie van hierdie huldigingspublikasie wil wys, raak die emosionele en geestelike impak (ook in die opsig van geestesgesondheid) van die huidige krisis op die mensheid en die skaal waarop ou en nuwe lesers hulle na die letterkunde wend - die taalsensitiwiteit en musikaliteit van die poësie en die lied, die katartiese dramatiek van die teater - om komplekse gewaarwordinge van onsekerheid, interne stryd en vertwyfeling, hoop, verlies, verlange en frustrasie onder woorde te help bring.

Verskeie bydraes in die publikasie is gemoeid met wat, soos dit nou lyk, onuitputlike aspekte van Louw se poësie is: sy vermoë om onder meer die groot spanningsvelde en dilemmas van menswees onder verskillende omstandighede te laat bly weerklink. Met die insig wat ouderdom bring, tree Joan Hambidge in 'n vyftal gedigte in gesprek met van Louw se gedigte, van haar eie vroeëre digterlike gesprekke met hom asook dié van ander digters wat al só met hom in gesprek getree het. Heilna du Plooy bied weer, met erkenning aan die talle verskillende lesings deur die jare van die enigmatiese "Groot ode" uit Tristia, 'n lesing van die gedig as 'n intiem persoonlike liefdeselegie. Tristia figureer ook as klankbord in ander bydraes, soos dié van Hein Viljoen (wat ook Nuwe verse opnuut lees) en Nerina Bosman. Willem Botha herlees, soos ons reeds gesien het, Germanicus en Marisa Keuris herbeskou Die pluimsaad waai ver en hulle bydraes stel in dié proses Luc Renders se afskrywing van Louw se dramauitset in 'n ander lig. Johann Lodewyk Marais herlees Louw se Raka en "Die swart luiperd" in die lig van die vernoude gaping tussen mens en dier wat beskouings in dierestudies die afgelope jare teweeggebring het en, aansluitend, Helize van Vuuren "Die narwal". Van Vuuren herlees voorts "Klipwerk" en "Die beiteltjie" as verse wat intens betrokke is, onderskeidelik by die wortels van Afrikaans én in sosio-politieke verband. En Benda Hofmeyr, ten slotte, neem "Miskien ook sal ons sterwe" uit Die halwe kring (1937) as vertrekpunt in haar betoog vir "hoog lewe" in sonderlinge tye en plekke in die "gees van voortdurende weerstand". 
Die foto op die buiteblad van die huldigingspublikasie is volgens 'n mededeling deur Reinet Kemp, dogter van Van Wyk Louw, iewers gedurende die sestigerjare tydens 'n fotosessie by die Louw-woning in Kinrossweg, Parkview, geneem deur 'n fotograaf van die Amerikaanse tydskrif LIFE. Dit is 'n foto wat op onverwagse maniere "meepraat" tydens wat in die Afrikaanse mond nou bekend staan as die grendeltyd. Dit roep ook die vensters op van een van Louw se roerendste gedigte, gedig " $X$ " in Tristia, waarmee Heilna du Plooy op Versindaba as deel van die digterlike gespreksreeks "NP van Wyk Louw 50" in gesprek tree, en, in hierdie publikasie, in twee gedigte, ook Joan Hambidge. Dit is 'n gedig waaruit talle emosies en onsekerhede spreek en wat danksy die teenstrydige aansprake - vir wie was die gedig bedoel, wie is die aangesprokene, aan wie is die gedig gegee? - ondanks ons persoonlike menings daaroor altyd onherroeplik oop sal bly vir elke nuwe leser en vertolker, vir elke nuwe waarnemer om dit in nuwe situasies opnuut van toepassing te maak. Sonder voorskrifte oor hoe om die gedig en voorbladfoto in gesprek te stel, druk ek die gedig hier af (met net 'n suggestie om ook Hambidge se gedig verder aan in dié publikasie te lees):

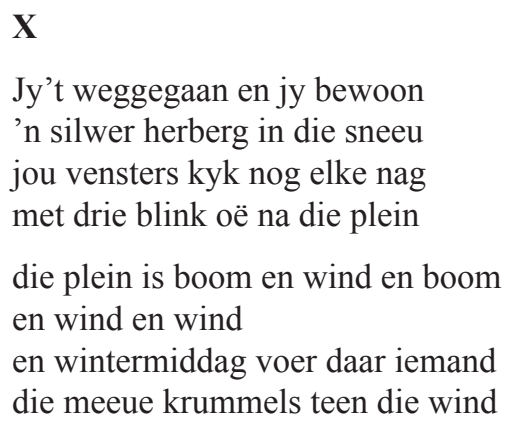

(Tristia, p.14)

Ten slotte, hier sonder verduideliking, 'n ongepubliseerde kwatryn waarmee Daniel Hugo, ook op Versindaba, in gesprek tree en wat hy ter plaatse verduidelik, 'n kwatryn wat verskil van die vyfreëlige weergawe van die gedig waarna Jacques van der Elst in sy Van Wyk Louwgedenklesing verwys en waarna Joan Hambidge op haar beurt in Woorde wat weeg verwys:

Die glas is deurskyn in my hand tienduisend myl lê Sutterland

- 'n silwer herberg in die sneeu -

die Here weet hoe beef die hand.

Hierdie publikasie is die kulminasie van 'n tweejaarprojek; die eerste uitnodigings is reeds in Junie 2018 gerig. My spesiale dank aan almal wat die uitnodiging aanvaar en meegewerk het om die vyftigste herdenkingsgeleentheid van NP van Wyk Louw se sterfjaar 'n uitsonderlike geleentheid te help maak. Opregte dank ook aan die hoofredakteur van Tydskrif vir Geesteswetenskappe, prof. Ina Wolfaardt-Gräbe, en die reeksredakteur van die Hertzogpryswennerhuldigings, prof. Jacques van der Elst, vir die beskikbaarstelling van hulle publikasieforums vir die geleentheid. Ook aan Tisa Viviers, Tom McLachlan, Elzabé Vosloo, Ina en Jacques vir elkeen se aandeel agter die skerms om die eindproduk betyds gelewer te kry, vanaf die eerste tot laaste rondtes taalversorging en teksredigering, beide van die afsonderlike 
bydraes en die byeengebringde manuskrip, die samestelling van die manuskrip vir elektroniese publikasie en vir die drukproses en tussendeur die nimmereindigende proses van proeflees, proeflees, proeflees!

Ten slotte wil ek graag ook erkenning gee aan die span kritiese eerste lesers van die bydraes in hierdie publikasie, vir hulle tyd en moeite, en vir die waardevolle kommentaar wat die peil van die afsonderlike stukke net ten goede gekom het.

RONÉL JoHL

Gasredakteur

11 Junie 2020

\section{BIBLIOGRAFIE}

Antonissen, Rob. 1962. Kern en tooi: Kroniek van die Afrikaanse lettere 1951-1960. Kaapstad: Nasou. Benton, Michael. 2009. Literary Biography. An Introduction. Chichester, West Sussex: John Wiley \& Sons Ltd.

Bezuidenhout, Andries. 2018. Utopiese verbeelding en Afrikaans: 'n Gesprek met T. Dunbar Moodie en N.P. van Wyk Louw. https://www.uj.ac.za/faculties/humanities/Department-of-Afrikaans/Pages/NP-van-Wyk-Louw-Lesings.aspx.

Bradford, Richard (ed.). 2019. A Companion to Literary Biography. Chichester, West Sussex: John Wiley $\&$ Sons Ltd.

Burger, W. 2015. Historiese korrektheid en historiese fiksie: 'n respons. Tydskrif vir Letterkunde 5(2):7896.

Claassen, JM. 2013. N.P. Van Wyk Louw: Germanicus translated and with an introduction. London: Dragonfly eBooks. https://www.smashwords.com/books/view/314998 (Mei 2013 gelaai).

Clarkson, Carrol. 2014. J.M. Coetzee: 'n Geskryfde Lewe./J. M. Coetzee: A Life in Writing. Life Writing, 11(2):263-270.

Cloete, T.T. 1963. Op die woord af. Kaapstad: Nasionale Boekhandel.

Head, Dominic. 2013. JM Coetzee: A Life in Writing, By JC Kannemeyer, Trans. Michiel Heyns.The Irish Times. 17 October 2013. https://www.irishtimes.com/culture/books/jm-coetzee-a-life-inwriting-by-jc-kannemeyer-trans-michiel-heyns-1.1481912.

Kannemeyer, JC. 2011. JM Coetzee - 'n Geskryfde lewe. Johannesburg: Jonathan Ball.

Kannemeyer, JC. (Michiel Heyns tr.). 2012. JM Coetzee: A Life in Writing. Scribe.

Kapp, Tertius. 2015. "met bier en bloed en dans en trom": Afrikaanse kunstefeeste en N.P. van Wyk Louw se kultuurkritiek. https://www.litnet.co.za/met-bier-en-bloed-en-dans-en-trom/.

Louw, NP van Wyk. 1956. Germanicus. Kaapstad: Tafelberg.

Louw, NP van Wyk. 1970. Rondom eie werk. Kaapstad \& Johannesburg: Tafelberg.

Muller, Stephanus. 2014. Nagmusiek. Johannesburg: Fourthwall Books.

Steyn, JC. 1998. Van Wyk Louw. 'n Lewensverhaal I. Kaapstad: Tafelberg.

Steyn, J.C. 2019. Verset en opbou. Skrywers en politici as aktiviste vir Afrikaans. Centurion: Kraal Uitgewers.

Van Coller, HP. 2019. Representasie as strategiese posisionering: J.C. Steyn se biografieë van Piet Cillié en M.E.R. In Van Niekerk, Angelique, HP van Coller \& Bernard Odendaal, (reds.). 2019. J.C. Steyn en Afrikaans. 'n Viering. Stellenbosch: Sun Media, pp. 269-295.

Van der Westhuizen, Johann. 2020. Wil jy bietjie regter speel. Rapport, 3 Mei, p. 7.

Viljoen, Louise. 2014. Die rol van Nederland in die transnasionale beweging van enkele Afrikaanse skrywers. Internationale Neerlandistiek. 52(1):3-26.

Willemse, Hein. 2019. LitNet Akademies-resensie-essay: Verset en opbou deur JC Steyn. LitNet Akademies. https://www.litnet.co.za/litnet-akademies-resensie-essay-verset-en-opbou-deur-jc-steyn/ 